\title{
IDENTIFYING REASONS FOR A LACK OF METHOD APPLICATION IN ENGINEERING DESIGN PRACTICE - AN INTERVIEW STUDY
}

\author{
M. Eisenmann ${ }^{\otimes}$ and S. Matthiesen \\ Karlsruhe Institute of Technology, Germany \\ $\triangle$ matthias.eisenmann@kit.edu
}

\begin{abstract}
Design methods are seldom used in engineering design practice. The presented study aims at finding the alternative strategies for situations with a need for methodological support. Semi-structured interviews were conducted with ten experienced design engineers to identify causes of and strategies for those situations. Three strategy clusters could be identified: generating information, experience and method application. As the individual's and the team's experience compete with the application of methods, they are seen as reasons for a lack of method application.
\end{abstract}

Keywords: human behaviour, design strategy, design practice, design methods

\section{Introduction}

A primary goal of design research is to develop methods, which support designers throughout the whole process from generating early concept ideas for a new product until it enters the market. Despite of this goal, design methods show a low application rate in practice (e.g. Daalhuizen, 2014) even by experienced designers (Dorst, 2008). There are many hypotheses on the causes for this lack of method application in design practice, ranging from constraints of time and resources in industry to the usability of the developed methods (Jänsch, 2007) or missing responsibilities for the transfer of these methods into practice (Birkhofer, 2011). Studies investigating this lack of method application often focus on the methods themselves. Their goal is usually to find requirements for further development in order to improve usability, flexibility or acceptance of existing methods or to develop new methods (see e.g. Jänsch, 2007; Geis et al., 2008; Beckmann et al. 2014; Guertler, 2018). Other authors focus on the application and impact of design methods on industrial practice (Chakrabarti and Lindemann, 2016). The presented investigations have in common that they focus on methods and their application. What is left out of the investigation, is the design engineer and the situation he/she is in. Lindemann (2016) concludes that the impact of design research needs to be investigated more closely. This underlines that there is missing research that links academic method development within design research with the application of methods in engineering practice.

One possible approach is to identify, when there actually is a need for methodological support. It is assumed in the design research community that there is a general need for methods in design practice which is founded on the ill-structured character of design tasks (Simon, 1973; Jonassen et al., 2006) and the cognitive limitations of the designer (Jänsch, 2007; Ehrlenspiel and Meerkamm, 2017). Those assumptions are founded on experiences in studies and industrial practice, which illustrate the usefulness of methods for design activity. Those studies again focus on the method itself and not on the designer 
and the corresponding situation. Looking at the design process from the designer's perspective, there has to be a subjective need for methodological support to actually apply design methods.

That is why we agree with Dorst's (2008) and Badke-Schaub and Voute's (2018) opinion, that the designers' thinking and acting should be understood in more detail before new methods are developed. Therefore, this contribution aims at understanding the thinking and acting of designers during the design process. Dorst (2008, p. 7) specifies how those aspects should be included in design research:

\section{"[...] the process and content of design activity are connected with a model of the designer and the context in which designing is taking place."}

There are few approaches, which try to establish a model of the designer and connect it with the context of designing. For example, Daalhuizen et al. (2009) conducted an interview study to investigate uncertainty in the design process. The researchers describe the situations with a high degree of uncertainty as "non-routine situations". Those situations can be seen as situations with a need for methodological support as the designer does not know how to proceed and solve the situation intuitively. Daalhuizen et al. (2009) focus on the designer's view of the situation and describe those non-routine situations in more detail. They define three sources of uncertainty as categories for non-routine situations: The individual, the social context and the design task. In each of those categories, the absence of required knowledge and skills of the designer are mentioned as causes for uncertainty. The mentioned knowledge therefore addresses the content of design activity. To better understand the role of the designer's knowledge and skill, the causes within the contents of design activity - e.g. the task or the system that is developed - need to be investigated in more detail. We therefore conclude on the following research question:

\section{RQ1: What are causes for situations with a need for methodological support in engineering design practice?}

Daalhuizen et al. (2009) also describe designers' responses to non-routine situations. "Keep going" is one of the nine described responses and combines several strategies including the formal use of design methods. It remains unclear, what influences the designer to use either a method or another strategy, which possibly stands in competition with the design method. To better understand, why methods are seldom applied in design practice the strategies designers apply need be investigated in more detail. Those strategies include every activity that is undertaken to overcome the non-routine situation, such as asking a colleague or building a physical model. We therefore conclude on our second research question:

\section{RQ2: What kind of strategies do expert design engineers apply to respond to situations with a need for methodological support?}

\section{Method}

\subsection{Scientific approach}

As the main goal of this contribution is a deeper understanding of the reasons, why designers seldom apply design methods in design practice, the designer himself should be in the focus of the investigation. Interviews with design engineers make obtaining information across different projects and products possible and support the investigation of the knowledge and views of different participants (Ahmed, 2007b). To get more detailed information and to support the explorative approach semi-structured interviews with design engineers were chosen as method for data collection. Semi-structured interviews contain a fixed set of questions to be answered but do not prescribe a defined sequence and additionally leave room for follow-up questions which come up during the interview.

To exclude limited methodological knowledge as a reason for the lack of method application, design engineers who acquired their engineering $\mathrm{PhD}$ in institutes with a focus on engineering design methodology were chosen as group of possible interviewees. As PhD's are often in positions on a middle management level, they gain a detailed overview of many projects and are the ones to give advice when non-routine situations come up. Additionally, to reduce the influence of a single industry or company, the search for interviewees included multiple companies of differing sizes in southern Germany. 
An interview guideline was developed which directed the conversation to the discussion of nonroutine situations: The interviews were structured by an interview guide in three phases. The first phase was directed at gathering information on the field of work of the participant, which enabled a more detailed understanding of the occurring problems. Phase two aimed at finding a concise situation that can be described as non-routine situation. Phase three then had the goal to examine this situation with respect to the underlying causes and the applied strategies to cope with it.

The explorative character of this study design does not allow statistically found statements on causal relationships, but it nevertheless enables a deeper understanding of the situations that are explored. Especially semi-structured interviews make an in-depth investigation and the comparison of multiple views possible (Hussy et al., 2010).

\subsection{Data acquisition}

Ten engineering design experts with methodological knowledge from eight different companies could be acquired for the semi-structured interviews. The interviews took place in the participants' workplace in order to provide a familiar environment and to make the use of work-related information possible. Additionally, the interviewer had the possibility to gain insights in the interviewees' workplace. The interviews were conducted between January and March 2019. Table 1 lists the information on the Interviewees and the corresponding companies. When conducting such explorative and qualitative studies, the number of participants required is linked to the information that can be acquired through each new interview. As the rate of new insights distinctly decreased during the last two interviews, the number of ten participants is seen to be sufficient for this study.

Table 1. Data of design engineers (DE) who participated in the study

\begin{tabular}{|c|c|c|c|c|c|c|}
\hline$\#$ & $\begin{array}{l}\text { Company } \\
\text { field }\end{array}$ & $\begin{array}{c}\text { Company } \\
\text { size (no. } \\
\text { employees) }\end{array}$ & $\begin{array}{c}\text { Company } \\
\text { department }\end{array}$ & $\begin{array}{l}\text { Position in } \\
\text { company }\end{array}$ & $\begin{array}{c}\text { Experience } \\
\text { in years } \\
\text { (total) }\end{array}$ & $\begin{array}{c}\text { Experience } \\
\text { in years } \\
\text { (current } \\
\text { position) }\end{array}$ \\
\hline DE01 & Power Tools & 27,000 & R\&D & R\&D Expert & 15.5 & $\bar{~} 5$ \\
\hline DE02 & Robotics & 14,000 & $\mathrm{R} \& \mathrm{D}$ & Team leader & 16.5 & 4.5 \\
\hline DE03 & $\begin{array}{c}\text { Plant } \\
\text { Engineering }\end{array}$ & 650 & $\mathrm{R} \& \mathrm{D}$ & $\begin{array}{c}\text { Department } \\
\text { manager R\&D }\end{array}$ & 34 & 15 \\
\hline DE04 & $\begin{array}{c}\text { Automotive } \\
\text { Supplier }\end{array}$ & 30,000 & Predevelopment & $\begin{array}{c}\text { Design } \\
\text { engineer }\end{array}$ & 10 & 5 \\
\hline DE05 & $\begin{array}{l}\text { Machine } \\
\text { Tools }\end{array}$ & 13,500 & R\&D & $\begin{array}{l}\text { Department } \\
\text { manager }\end{array}$ & 14.5 & 2.5 \\
\hline DE06 & $\begin{array}{c}\text { Engineering } \\
\text { Design } \\
\text { Service } \\
\text { Provider } \\
\end{array}$ & 30 & $\begin{array}{c}\text { Company } \\
\text { Management }\end{array}$ & $\begin{array}{l}\text { Managing } \\
\text { Director }\end{array}$ & 22 & 17 \\
\hline DE07 & Power Tools & 27,000 & Predevelopment & $\begin{array}{c}\text { Technical } \\
\text { Project } \\
\text { Manager }\end{array}$ & 15 & 10 \\
\hline DE08 & Automotive & 10,000 & Predevelopment & $\begin{array}{c}\text { Department } \\
\text { Manager }\end{array}$ & 13 & 2 \\
\hline DE09 & $\begin{array}{l}\text { Machine } \\
\text { Elements }\end{array}$ & 50,000 & Predevelopment & Senior Expert & 16 & 2 \\
\hline DE10 & Automotive & 10,000 & Development & Team Leader & 10.5 & 2.5 \\
\hline
\end{tabular}

It is visible, that companies from a broad context of different fields of expertise and different sizes took part in the study. Also, all participants except DE04 (see Table 1) worked in leading positions in their company. In this way, the participants were able to contribute their own experience from projects carried out by themselves as well as that of their employees from various other projects. The interviews lasted between 40 and 60 minutes and were recorded and later transcribed for analysis. Additionally the 
interviewer took notes during the interview, which were digitalized afterwards. The interview guide contained different questions: The first question (1) was for the interviewees to define their field of work as concise as possible. Followed by a second question, (2) which kind of problems came up in their work and why they couldn't be solved right away. This led to a discussion of problem cases that indicated non-routine situations. Afterwards the interviewees were asked (3) how they responded to those and to other similar situations. Also they were asked (4) if there were any methods prescribed in the company to address those non-routine situations that had or had not been applied in the situations discussed. Depending on the detail of description, multiple follow-up questions were posed to gain a better understanding of the situations described and to assess, how often methods were used. Afterwards, questions (2) - (4) were repeated iteratively to identify various similar situations, the underlying causes and the applied strategies.

\subsection{Data analysis}

The transcribed interview protocols were analysed following Mayring's (1991) procedure for qualitative content analysis. As a first step, the data was paraphrased and a first coding was conducted to find similar topics in the different interviews to group the found segments. Afterwards a coding process was conducted as proposed by Glaser and Strauss's (2017) grounded theory approach to support the explorative character of the study. The approach consists of three steps: (1) open coding, (2) axial coding and (3) selective coding.

The open coding (1) produced segments labelled with multiple descriptive keywords resulting from the coder's interpretation of the content. In this step, two coders interpreted each segment independently. Axial coding (2) then made grouping different segments and establishing causal links between multiple segments possible. In the last step of selective coding (3), groups of segments were chosen as categories and redundant segments were left out. The categories found were then organised in clusters if possible. As suggested by Strauss (1990) coding in the second and third step was paralleled and the results were generated iteratively. This was done to include learnings of the coders and to make the resulting categories as concise as possible.

To summarize the findings, frequencies of the identified categories were calculated by occurrence per interview. Like this, an overview was possible on how many of the participants mentioned the respective causes and strategies.

\section{Results}

\subsection{Causes for situations with a need for methodological support}

To answer the first research question (RQ1) "What are causes for situations with a need for methodological support in engineering design practice?" different causes were identified in the coding process and grouped into categories. The resulting categories, a description of each category and their frequency of occurrence in the interviews are shown in Table 2. Six different categories (C1 - C6) have been identified by focusing on the content and the process of design activity.

It is visible in Table 2, that in most of the conducted interviews, causes for non-routine situations can be attributed to either the design task $(\mathrm{C} 1, \mathrm{C} 2)$

DE03: "Here, in fact, the solution space is infinitely wide. And it's often difficult to compile a specification sheet at all"

or the system's intricacy and complex interactions $(\mathrm{C} 3, \mathrm{C} 4)$

\section{DE01: "This already shows that it's pretty difficult to think of the sum of all things."}

Especially the ill-defined design task (C1) seems to be a source for uncertainty and therefore for non-routine situations. Factors like the accessibility of information (C5) seem to play only a minor role.

The described complex system interactions (C4) include not only the interactions within the technical system itself, but also the interactions with the environment it is operating in. 
Table 2. Causes for non-routine situations

\begin{tabular}{|c|c|c|c|}
\hline \# & Cause & Description & $\begin{array}{c}\text { Freq. } \\
\text { [1..10] }\end{array}$ \\
\hline $\mathrm{C} 1$ & $\begin{array}{l}\text { Ill-defined } \\
\text { design task }\end{array}$ & $\begin{array}{l}\text { In many cases the design problem, which design engineers have to solve, } \\
\text { involves a high degree of uncertainty. Tasks comparable to "make this } \\
\text { system } 20 \% \text { more efficient" include only the target value that has to be } \\
\text { achieved but the possible modifications to the system to reach this target are } \\
\text { not defined. Additionally there is usually a high number of possible ways to } \\
\text { modify the systems which may interact with each other. }\end{array}$ & 8 \\
\hline $\mathrm{C} 2$ & $\begin{array}{l}\text { Competing } \\
\text { target } \\
\text { values }\end{array}$ & $\begin{array}{l}\text { There are many target dimensions, which have to be met in product } \\
\text { development. The design engineer has to evaluate which requirement is to be } \\
\text { achieved with which degree of quality. Additionally, in interdisciplinary } \\
\text { design, different disciplines set different target values, which result in } \\
\text { competing strategies. Those target values add to the complexity of the design } \\
\text { problem that is to be solved. }\end{array}$ & 6 \\
\hline C3 & $\begin{array}{l}\text { Intricate } \\
\text { systems }\end{array}$ & $\begin{array}{l}\text { Modern technical systems often consist of a high number of single parts. } \\
\text { Each of these parts has its own requirements and specifications. This adds up } \\
\text { to an extensive number of requirements and data to be determined, which } \\
\text { makes it hard not to forget any relevant aspects in the development process. }\end{array}$ & 6 \\
\hline $\mathrm{C} 4$ & $\begin{array}{l}\text { Complex } \\
\text { system } \\
\text { interactions }\end{array}$ & $\begin{array}{l}\text { In today's technical systems, many components interact with each other in } \\
\text { different ways. Thermal, mechanical, chemical and electrical interactions add } \\
\text { up in long chains. Additionally systems get influenced by the environment } \\
\text { they operate in (Matthiesen, 2011). These various interactions especially } \\
\text { occur in mechatronic systems. This makes it nearly impossible to identify all } \\
\text { relevant interactions (Matthiesen, 2011) before there is a prototype ready for } \\
\text { testing. }\end{array}$ & 6 \\
\hline $\mathrm{C} 5$ & $\begin{array}{l}\text { Information } \\
\text { accessibility }\end{array}$ & $\begin{array}{l}\text { To design a system with a high degree of functionality it is necessary to } \\
\text { include all relevant information. This information ranges from a single } \\
\text { assessment of a necessary tolerance to a precise documentation of a reference } \\
\text { system. In some cases, this information is not available because of } \\
\text { confidentiality agreements or because a client does not allow to collect } \\
\text { information on site. }\end{array}$ & 2 \\
\hline C6 & $\begin{array}{l}\text { Time } \\
\text { pressure }\end{array}$ & $\begin{array}{l}\text { For financial reasons development time is restricted and there are usually } \\
\text { many competitors for the same market. This means that time-to-market is a } \\
\text { crucial factor in product development. This results in a high time pressure for } \\
\text { the development of a new product. }\end{array}$ & 4 \\
\hline
\end{tabular}

One of the participants described an example that included the influence of a lower barometric pressure on the system when used in a high-altitude country. This led to malfunctions of the product and therefore to refusals for this specific country.

\subsection{Response strategies}

The identified response strategies to answer the second research question (RQ2) "What kind of strategies do expert design engineers apply to respond to situations with a need for methodological support?" are shown in Table 3. Nine strategies (S1 - S9) could be identified and grouped in three clusters: Generating information, experience and method application. Table 3 shows the strategies with their description and frequency.

The identified clusters were mentioned with a varying frequency: All participants applied strategies contained in the clusters generating information and experience. The preferred strategies in those clusters seem to be the use of prototypes and simulation (S2) as well as the use of team experience (S4) which nine out of ten participants applied. In the cluster method application there are eight occurrences of the containing categories in comparison to 14 in the cluster generating information and 17 in cluster experience. Seven out of ten participants mentioned the application of methods to respond to non-routine situations. One of those seven participants applied both strategies of applying methods explicitly and of adapting them for the use in his company. 
Table 3. Design engineers' response strategies for situations with a need for methodological support

\begin{tabular}{|c|c|c|c|c|}
\hline Cluster & $\#$ & Strategy & Description & $\begin{array}{l}\text { Freq. } \\
{[1 . .10]}\end{array}$ \\
\hline \multirow{2}{*}{ 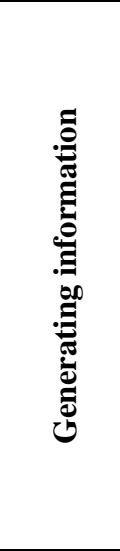 } & $\mathrm{S} 1$ & $\begin{array}{l}\text { Analysing existing } \\
\text { data }\end{array}$ & $\begin{array}{l}\text { Design engineers can use data that was gathered on a similar } \\
\text { system or a previous product generation to obtain additional } \\
\text { information. It is also possible to interpret data from clients to } \\
\text { generate new information relevant for the actual development. } \\
\text { For example: If there is no information on user behaviour, data } \\
\text { collected in the field with a previous product generation can be } \\
\text { interpreted to gain insights on user behaviour (e.g. Germann et } \\
\text { al., 2019). }\end{array}$ & 6 \\
\hline & $\mathrm{S} 2$ & $\begin{array}{l}\text { Generating new } \\
\text { data by prototyping } \\
\text { or simulation }\end{array}$ & $\begin{array}{l}\text { Especially when developing a new system, it is unclear how the } \\
\text { system will perform in the long term or how its behaviour will } \\
\text { change because of wear or other effects. The testing of } \\
\text { prototypes and computer simulations (e.g. CAE) help to generate } \\
\text { data concerning such aspects and make gathering the relevant } \\
\text { information possible. }\end{array}$ & 9 \\
\hline \multirow{3}{*}{ 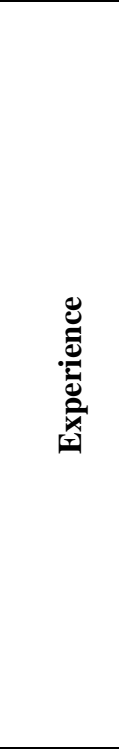 } & S3 & $\begin{array}{l}\text { Using own } \\
\text { intuition/experience }\end{array}$ & $\begin{array}{l}\text { Over the years, design engineers acquire different kinds of } \\
\text { experience. They design different products, see many solutions } \\
\text { fail and succeed what adds up to an intuitive understanding of the } \\
\text { product and the process of designing. They can use this } \\
\text { experience in various situations by recalling similar situations } \\
\text { and selecting appropriate solutions without explicitly evaluating } \\
\text { them. }\end{array}$ & 5 \\
\hline & S4 & $\begin{array}{l}\text { Using team's } \\
\text { intuition/experience }\end{array}$ & $\begin{array}{l}\text { Engineering design is usually a team activity that encompasses } \\
\text { the experience of all team members. In a well-functioning team, } \\
\text { design engineers can use their colleagues' experience if they do } \\
\text { not know how to proceed on their own or if they lack a piece of } \\
\text { information necessary for the next step. This high level of } \\
\text { communication between team members facilitates responding on } \\
\text { the problematic situations. }\end{array}$ & 9 \\
\hline & S5 & $\begin{array}{l}\text { Using customer's } \\
\text { intuition/experience }\end{array}$ & $\begin{array}{l}\text { Especially in long-term projects, design engineers build a close } \\
\text { connection to the customer in order to validate the progress of } \\
\text { development. This close connection to the customer can be used } \\
\text { to gain insights in reasons for requirements and to get helpful, } \\
\text { product- and environment-specific advice for the development. }\end{array}$ & 3 \\
\hline \multirow{4}{*}{ 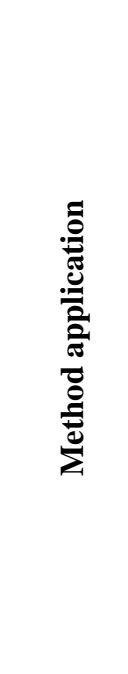 } & S6 & $\begin{array}{l}\text { Applying } \\
\text { prescribed methods }\end{array}$ & $\begin{array}{l}\text { Especially large companies try to condense their experience in } \\
\text { design project guidelines to make the development process more } \\
\text { effective and efficient. Those guidelines prescribe or suggest } \\
\text { processes and methods for defined phases in product } \\
\text { development. Also, some products might require the application } \\
\text { of methods by law, e.g. FMEA. }\end{array}$ & 3 \\
\hline & S7 & $\begin{array}{l}\text { Applying method } \\
\text { components }\end{array}$ & $\begin{array}{l}\text { Time pressure and other limiting factors lead to non-routine } \\
\text { situations, which demand a quick solution. Design engineers can } \\
\text { solve these kind of situations by applying only single steps or } \\
\text { components of methods. }\end{array}$ & 2 \\
\hline & S8 & $\begin{array}{l}\text { Formal use of } \\
\text { design methods }\end{array}$ & $\begin{array}{l}\text { If the design engineer knows a sufficient number of design } \\
\text { methods he/she can deliberately choose a suitable method for the } \\
\text { situation at hand autonomously. }\end{array}$ & 1 \\
\hline & S9 & $\begin{array}{l}\text { Adapting and } \\
\text { developing methods }\end{array}$ & $\begin{array}{l}\text { Even if the design engineer has a large portfolio of methods, it is } \\
\text { not always possible to find a suitable one for the situation at hand. } \\
\text { In this case, design engineers with a methodological background } \\
\text { can adapt and develop methods for the current situation. }\end{array}$ & 2 \\
\hline
\end{tabular}

Given the methodological background of the participants, it is surprising, that only a single participant mentioned the application of design methods that are not prescribed from third parties: 
DE09: "This is just at the beginning that we set up the solution tree, that we fill the morphological box and then start to discuss [...]"

Although nine out of ten participants use their team's experience to respond to non-routine situations, this has to be seen in a more differentiated perspective, as not every situation is suitable for the team's experience:

DE06: "Then you sit in the team, everyone wants to discuss along, and then there are again those with the big mouth. And then the system is determined as the ones with the big mouth want it to be."

Some participants explained, why they often do not work systematically anymore. They mention that their experience enables them to solve problems more intuitively:

DE06: "The information research becomes less and less over time, because through the experience with other projects, there is always someone who says: 'We could do it that way'."

Another reason that was mentioned by multiple participants, is that their daily work leaves no room for method application:

DE10: "Yes, perhaps it would be advisable to be more methodical in one case or another, but it's hard to get around in day-to-day business."

Five out of seven participants who mentioned design method application also reported, they wanted to use methods more often but only seldom did so. DE01 and DE09 were the only participants who reported to use design methods - adapted or original versions - quite regularly without prescription by their company or law.

\section{Discussion}

\subsection{Causes for situations with a need for methodological support}

The results in section 3.1 show, that experts mainly identify the design task and the system's intricacy as well as its complex interactions as causes for non-routine situations. These findings align with the results of Jonassen et al. (2006) who also identify the ill-structured character of engineering problems (compare $\mathrm{C} 1$ in Table 2) and conflicting goals (compare $\mathrm{C} 2$ in Table 2) as characteristics of engineering workplace problems. In the current study, there was no evidence for individual or social causes of non-routine situations as described by Daalhuizen et al. (2009), but they also described the complexity of the design task as one source for uncertainty. One reason for the lack of descriptions that could be linked to individual or social causes lies the focus of the interviews on the content and process of designing rather than the social context. This enables a new view on the subject as was intended for this study.

The current study provides a deeper understanding of content- and process-related aspects of designing as it introduces the system's intricacy (see C3 in Table 2) as well as its complex interactions (see $\mathrm{C} 3$ in Table 2) with its own components and the environment as factors that foster situations with a need for methodological support. The new findings on causes for non-routine situations can be summarized:

(1) The intricacy of modern technical systems is a challenge for design engineers. This intricacy makes it difficult not to forget single aspects during design. (2) Complex interactions in technical systems pose challenges to design engineers. Those interactions can occur within the system itself as well as with the environment.

These findings indicate multiple factors that trigger a need for methodological support. Design research provides various design methods to address these factors. The system 's intricacy as well as the occurring complex interactions may be addressed by using modelling approaches like the Contact and Channel Approach (Grauberger et al., 2019) or the Design Structure Matrix (Yassine and Braha, 2003). 


\subsection{Response strategies for situations with a need for methodological support}

According to the results presented in section 3.2 there are three clusters of strategies to respond to non-routine situations: Generating information, experience and method application. Addressing experience, many participants mentioned their intuitive "gut feeling" which they developed for the product and the process as well. It seems logical, that experience linked to the product competes with strategies for generating information like prototyping and simulation whereas experience linked to the process of designing competes with method application, as methods provide explicit instructions on how to proceed when the designer is stuck. Moreover, this aligns with the findings of Ling et al. (2014) who found that designers' intuition influences the search for information, comparable to the cluster generating information, and also influences the generation and selection of ideas, comparable with method application. Ahmed (2007a) also describes "product knowledge" and "process knowledge" and finds, that sufficient product knowledge is necessary to set up tests, what confirms the influence of experience on prototyping and simulation. As experience spans knowledge attributed to the product that is to be designed as well as to successful processes to reach a satisfactory product, the use of experience influences both dimensions of knowledge suggested by Ahmed (2007a). Design methods should make previously successful, proven processes available by making them explicit. In this view, the formal use of design methods and the use of experiential knowledge of proven processes compete with each other as they address the same non-routine situations. Daalhuizen and Badke-Schaub (2011) discovered that experience reduces the formal use of design methods in planning situations in a laboratory context. As the current study discussed cases from industry supplied by experienced practitioners, it additionally shows this effect in engineering design practice. Moreover, not only could the influence of experience of the individual be shown, also a new dimension was identified, that is the experience of the design team. This experience also seems to compete with the use of design methods. As described before, the rate of method usage by the participants - who are specially trained in methodology - was surprisingly low. This might originate from the frequent use of experience. This supports the view of Jänsch (2007) that design methods are nothing else than experiences of successful design processes made explicit. Those implicit methods are applied with less time and effort (Ehrlenspiel, 1999). This is why they compete with the formal use of design methods. This view is supported by various participants, who addressed the lack of time to use methods in day-to-day business. In some cases they used the strategy application of method components instead to save time and effort in comparison to the application of the whole method:

DE06:" [...] when we make suggestions, then we first rate with thumbs up / thumbs down. [...] but unweighted, without a number behind it. Simply described qualitatively"

Another aspect is the high value the participants themselves see in their experience and intuition. This experience was often mentioned as the "engineer's gut feeling":

DE09: “[...] as an engineer you should listen to your gut feeling. Because this gut feeling represents an incredible amount of experience that you can't grasp. It's not necessarily an equation. [...] So I'd rather listen to an experienced engineer with his gut feeling than to an inexperienced engineer with a calculation. Because the calculation can be wrong, the gut feeling is often right [...]"

Badke-Schaub and Eris (2014) also identified that the use of intuition requires a certain degree of experience and simultaneously stress the high value of intuition. The insights that could be found by analysing the strategies design engineers apply to respond to non-routine situations can be summarized as follows:

\section{(1) Design engineers highly value their experience as tool to help them when solving problems during design. (2) The experience of design engineers seems to lead to a reduced application of design methods in practice. This effect is also visible for the experience of the design team.}

Regarding the lack of method application, this means, that the role of intuition or experience as a supplement for the formal use of design methods should be investigated further. Particularly the 
distinction, when the design engineer's or the design team's experience is suitable to solve the situation and when it is more advisable to use known design methods remains unclear. This should be addressed by representing non-routine situations in a study design and comparing the use of experience and the formal use of design methods. As experienced design engineers tend to use their experiential knowledge rather than design methods in their original form, it seems advisable to develop design methods especially for unexperienced design engineers. That means, assessing the needs of unexperienced designers is necessary.

\section{Conclusion and outlook}

The main goal of the interview study presented was to identify reasons, why methods are seldom applied in engineering design practice. This was approached by identifying causes for situations which imply a need for methodological support as well as strategies to respond to those situations. Ten engineering design experts with methodological knowledge from eight different companies were interviewed to collect the necessary data. The results after coding and categorising the semi-structured interviews were six different causes as well as three clusters of strategies containing a total of nine strategies.

Concerning the causes of non-routine situations the interviews showed, that the ill-defined nature of the design task and the system's intricacy as well as its complex interactions play an important role for the need of methodological support. By comparing the frequencies of the three identified clusters of strategies: generating information, experience and method application a surprisingly low rate of method application could be identified compared to the other clusters.

A deeper analysis showed, that the applied strategies address product knowledge as well as process knowledge, which are both key competencies of design engineers. The use of individual experience as well as of the design team's experience seems to compete with the other strategy clusters for both knowledge types. We therefore conclude that the use of methods gets reduced by the use of experience that is in most cases the intuition of the designer or the design team as a whole. This seems to be one of the reasons, why methods are seldom applied in engineering design practice.

As this competing strategy of using experience might be superior to the use of methods in some cases this needs to be investigated further in design research. By investigating, in which situations and under which conditions it is more advisable to use the own or the team's experience instead of a design method in its originally intended form, it gets possible to identify a more objective need for methodological support in design practice.

\section{Acknowledgement}

This publication was created in the context of the project "Understanding what constitutes the engineering profession" which was sponsored by the Vector Stiftung under the funding code P2018-0061. The Authors additionally would like to thank the interviewees for taking part in the study.

\section{References}

Ahmed, S. (2007a), “An Industrial Case Study: Identification of Competencies of Design Engineers”, Journal of Mechanical Design, Vol. 129 No. 7, pp. 709-716. https://doi.org/10.1115/1.27238070

Ahmed, S. (2007b), "Empirical Research in Engineering Design", Journal of Design Research, Vol. 6 No. 3, pp. 359-380. http://doi.org/10.1504/JDR.2007.016389

Badke-Schaub, P. et al. (2014), "A Theoretical Approach to Intuition in Design: Does Design Methodology Need to Account for Unconscious Processes?", In: An Anthology of Theories and Models of Design, Springer, London, pp. 353-370. https://doi.org/10.1007/978-1-4471-6338-1_17

Badke-Schaub, P. and Voute, E. (2018), "Design Methodology: Where do you go?", Proceedings of the DESIGN 2018 / 15th International Design Conference, Dubrovnik, Croatia, May 21-24, 2018, The Design Society, Glasgow, pp. 25-32. https://doi.org/10.21278/idc.2018.0550

Beckmann, G., Gebhardt, N. and Krause, D. (2014), "Transfer of Methods for developing Modular Product Families into Practice - An Interview Study", Proceedings of the DESIGN 2014 / 13th International Design Conference, Dubrovnik, Croatia, May 19-22, 2014, The Design Society, Glasgow, pp. 121-130.

Birkhofer, H. (2011), The Future of Design Methodology, Springer, Heidelberg. https://doi.org/10.1007/978-085729-615-3 
Chakrabarti, A. and Lindemann, U. (2016), Impact of Design Research on Industrial Practice, Springer, Cham. https://doi.org/10.1007/978-3-319-19449-3

Daalhuizen, J., Badke-Schaub, P. and Batill, S.M. (2009), "Dealing with uncertainty in design practice: issues for designer-centered methodology". Proceedings of the ICED 09 / 17th International Conference on Engineering Design, Vol. 9, Human Behavior in Design, Palo Alto, United States, August 24-27, 2009, The Design Society, Glasgow, pp. 147-158.

Daalhuizen, J. and Badke-Schaub, P. (2011), "The use of methods by advanced beginner and expert industrial designers in non-routine situations: a quasi-experiment", International Journal of Product Development, Vol. 15 No. 1/2/3, pp. 54-70. https://dx.doi.org/10.1504/IJPD.2011.043661

Daalhuizen, J. (2014), Method Usage in Design: How methods function as mental tools for designers, [PhD Thesis], TU Delft. https://doi.org/10.4233/uuid:4ac01165-c6b5-4057-a2fe-3418907f251e

Dorst, K. (2008), "Design research: a revolution-waiting-to-happen", Design Studies, Vol. 29, pp. 4-11. https://dx.doi.org/10.1016/j.destud.2007.12.001

Ehrlenspiel, K. (1999), "Praktiker minimieren ihren Konstruktionsaufwand mit unbewußt erlernten Methoden", In: Franke, H.J., Krusche, T. and Mette, M. (Eds.), Konstruktionsmethodik - Quo vadis?, Shaker, Aachen, pp. 31-42.

Ehrlenspiel, K. and Meerkamm, H. (2017), Integrierte Produktentwicklung: Denkabläufe, Methodeneinsatz, Zusammenarbeit, Hanser, Munich. https://doi.org/10.3139/9783446449084

Geis, C. et al. (2008), "Methods in practice - A study on requirements for development and transfer of design methods", Proceedings of the DESIGN 2008 / 10th International Design Conference, Dubrovnik, Croatia, May 19-22, 2008, The Design Society, Glasgow, pp. 369-376.

Germann, R., Jahnke, B. and Matthiesen, S. (2019), “Objective usability evaluation of drywall screwdriver under consideration of the user experience”, Applied Ergonomics, Vol. 75, pp. 170-177. https://doi.org/10.1016/ j.apergo.2018.10.001

Glaser, B.G. and Strauss, A.L. (2017), The Discovery of Grounded Theory, Routledge, New York. https://doi.org/ $10.4324 / 9780203793206$

Grauberger, P. et al. (2019), "The contact and channel approach - 20 years of application experience in product engineering", Journal of Engineering Design. https://doi.org/10.1080/09544828.2019.1699035

Guertler, M.R. (2018), "How to design Methods for Application - Empirical Insights from Industry", Proceedings of the DESIGN 2018 / 15th International Design Conference, Dubrovnik, Croatia, May 21-24, 2018, The Design Society, Glasgow, pp. 1161-1172. https://doi.org/10.21278/idc.2018.0169

Hussy, W., Schreier, M. and Echterhoff, G. (2010), Forschungsmethoden in Psychologie und Sozialwissenschaften für Bachelor, Springer, Berlin. https://doi.org/10.1007/978-3-642-34362-9

Jänsch, J. (2007), Akzeptanz und Anwendung von Konstruktionsmethoden im industriellen Einsatz: Analyse und Empfehlungen aus kognitionswissenschaftlicher Sicht, [PhD Thesis], TU Darmstadt.

Jonassen, D., Strobel, J. and Chwee, B.L. (2006), "Everyday Problem Solving in Engineering: Lessons for Engineering Educators", Journal of Engineering Education, Vol. 95 No. 2, pp. 139-151. https://doi.org/10. 1002/j.2168-9830.2006.tb00885.x

Lindemann, U. (2016), "Impact of Design Research on Practitioners in Industry", In: Chakrabarti, A. and Lindemann, U. (Eds.), Impact of Design Research on Industrial Practice, Springer, Cham, pp. 223-232. https://doi.org/10.1007/978-3-319-19449-3_14

Ling, T., Xiao, Y.G. and Badke-Schaub, P.G. (2014), "How Intuition affects Designers' Decision Making: An Interview Study", Proceedings of the DESIGN 2014 / 13th International Design Conference, Dubrovnik, Croatia, May 19-22, 2014, The Design Society, Glasgow, pp. 537-548.

Matthiesen, S. (2011), "Seven Years of Product Development in Industry - Experiences and Requirements for supporting Engineering Design with 'Thinking Tools"', Proceedings of the ICED 11/18th International Conference on Engineering Design, Vol. 9, Design Methods and Tools pt. 1, Lyngby/Copenhangen, Denmark, August 15-19, 2011, The Design Society, Glasgow, pp. 236-245.

Mayring, P. (1991), "Qualitative Inhaltsanalyse”, In: Flick, U., Kardoff, E.V., Keupp, H., Rosenstiel, L.V. and Wolff, S. (Eds.), Handbuch qualitative Forschung: Grundlagen, Konzepte, Methoden und Anwendungen, Beltz, Munich, pp. 209-213.

Strauss, A.L. (1990), "Systematic Coding in Qualitative Research", Bulletin de méthodologie sociologique, Vol. 27, pp. 52-62. https://doi.org/10.1177/075910639002700103

Simon, H. (1973), "The structure of ill-defined problems", Artificial Intelligence, Vol. 4 No. 3-4, pp. 181-201. https://doi.org/10.1016/0004-3702(73)90011-8

Yassine, A. and Braha, D. (2003), "Complex Concurrent Engineering and the Design Structure Matrix Method", Concurrent Engineering, Vol. 11 No. 3, pp. 165-176 